\title{
19
}

\section{Pedagogical Entanglements and the Cold War: A Comparative Study on Opening History Lessons on the Cold War in Sweden and Switzerland}

\section{Robert Thorp}

The Cold War was a complex series of events that came to have a great impact on most countries in Europe. This article analyses two lower secondary schools' opening lessons on the Cold War, one taught in Sweden and the other in Switzerland. The study finds that the opening lessons vary to a great extent, regarding both what content is covered but also how that content is covered. Whereas the Swiss lesson predominantly focuses on establishing a critical narrative of the origins of the Cold War conflict, the Swedish lesson disseminates what could be considered a traditional narrative of the Cold War. The lessons also differ due to the different forms of educational media employed by each teacher. While the Swiss teacher makes use of caricatures to instigate pupil-oriented discussions about what caused the Cold War, the Swedish teacher uses personal analogies and a video during class. The study, however, finds that neither teacher engages with the contingencies of history culture that affect historical content and how we approach it; instead both disseminate a closed rendering of the history of the Cold War.

R. Thorp (四)

University of Stockholm, Stockholm, Sweden

The University of Newcastle, Newcastle, NSW, Australia e-mail: robert.thorp@edu.su.se; robert.thorp@newcastle.edu.au

(C) The Author(s) 2019 


\section{Introduction}

Teaching history is a complex enterprise. There are always a number of factors that come into play when a teacher sets out to disseminate a certain historical content. Not only should the teacher reflect on what content to cover in a teaching situation, but he or she also needs to reflect on how that content should be presented to the pupils. Here, the preconceptions and prior knowledge of the pupils needs to be taken into account (Duraisingh 2017; Stymne 2017), as well as that of the teacher (Thorp 2016). Furthermore, history education can also be understood as a kind of cultural endeavor in which collective memories, personal experiences, beliefs and opinions as well as official curricula are at work (Furrer and Gautschi 2017). History teachers have to navigate these challenges whenever they set out to teach their subject. Approaching history teaching from this perspective means that we come to regard such a process as a kind of entangled activity where both subject-related constraints and social and cultural constraints come into play (Parkes 2013; Thorp 2016).

Indeed, the subject of history itself might also be regarded as subject to a similar kind of entanglement. One important aspect of history is the study of the past with the aim to understand how it has influenced societies today. However, and this is another important aspect, history must always be reconstructed and is, thus, contingent on this reconstruction. With this view, it follows that knowing history basically means grasping two different but inter-related concepts: the existence of facts about the past and its events and the concept that history is also always a reconstruction of this past (Wineburg 2001; Parkes 2011). Moreover, whenever we make use of history we continuously reconstruct the reconstruction of the past in what perhaps might be called a never-ending cycle of reconstruction. German philosopher Hans-Georg Gadamer posited the idea that an awareness of how history is always constructed within a certain context for certain purposes, how it is always the subject of historicity, was one of the greatest achievements of modern thought (Gadamer 1975). This awareness of historicity, or historical consciousness, it could be argued, is an essential component in an understanding of history that seeks to disentangle an entangled historical subject. This in itself poses 
another difficult challenge to history teachers. Following this line of argumentation, the Cold War can serve a particularly interesting historical topic to study due to its historical proximity and looming consequences for many (if not all) European countries. Furthermore, the Cold War as a historical topic allows historical and didactical entanglements to come to the fore. It is a historical event that goes beyond simply having a historical relevance since it also affects ideological, social and cultural conceptions of ourselves, our national and international affairs (Furrer 2017). From a disciplinary perspective, the Cold War is also the perfect case study because it is still close to us; we have, therefore, an excellent opportunity to explore how it has been constructed as a historical event. The binary opposition between the USA and the USSR at the core of the event also makes it ideal for these purposes, since we have two agents who deliver different narratives in regards to the same historical event. However, since the Cold War is an historical event that goes beyond just being an historical event, it can also pose great challenges to history teachers, since it feeds into our basic common sense assumptions of how we should understand people, politics and the world, playing such a prominent part in European post-war societies. In other words, we might argue that the Cold War itself is a highly entangled historical subject.

In order to tease out what implications the interplay and ensuing entanglement between history, collective memory, personal experiences and classroom teaching practices have for the teaching of history, I wanted to study how teachers from two different national contexts taught the same historical subject. For these reasons, secondary school history teachers in Sweden and Switzerland were observed when they introduced a teaching unit on the Cold War to their students. The rationale here was not that I would be able to get at the historical cultures of these countries, or to be able to say something about how teachers in these two countries teach the Cold War in general. Rather, it was seen as an excellent opportunity to study how two teachers from two different contexts, who taught the same historical topic, went about delivering that same topic to their pupils. Thus, the focus of this study was to more deeply understand how these teachers dealt with the complexities and entanglements I have outlined above. Recent research on teaching history, assuming not only disciplinary difficulties in teaching history but also social and cultural ones 
has shown that matters of curricular demands, collective memory, cultural entanglement and awareness of historicity all play prominent roles in how history teachers perceive their subject, their own roles as educators and how to best teach the subject (Persson and Thorp 2017; Persson 2017; Thorp 2017; Zanazanian 2009). This study should be seen as a further exploration of this field of research into educating students in the subject of history.

Consequently, the aim of this article is to analyse how two history teachers from two different contexts approach the Cold War in a teaching situation and how they engage with the historicity of the historical content they disseminate. Attention will be given to the strategies and educational media the observed teachers used, as well as to how particular content was covered. The presentation below will start with an outline of the theoretical and methodological concerns regarding the teaching of history. Following on from this explanation, I will present the main results of the study, and then discuss how these results might be used to encourage further understanding of the cultural entanglements that characterise the teaching of history.

\section{Approach}

\section{Theoretical assumptions}

A basic theoretical assumption that has been made here is that history inevitably is a reconstruction of past events. This reconstruction in turn is subject to historicity in the sense that it is always contextually contingent (Thorp 2016). Historians (and others who produce accounts of history) always meticulously select and interpret past sources in order to construct history. In this sense history is always alienated from the past it wishes to reconstruct (cf. Roth 2012), and it is this alienation that gives rise to history as a serious methodological and critical study of past events (cf. Wilschut 2012, 47-52). Because of this inherent contingency in history, any historical narrative is open to scrutiny and is, in a way, provisional: other perspectives, methodologies and interests may generate 
other historical accounts using the same source material. Thus, it might be argued that the merits of any historical account lie not so much in the actual history it conveys, but instead in the methodological aspects of how that particular historical narrative was produced. This means that epistemological concerns take the front seat, particularly when it comes to the academic subject of history (Thorp 2016).

Yet there is also another aspect of history that needs to be taken into account, especially when it comes to teaching history. History is not only the careful reproduction of past events through a critical methodological inquiry, it is also a central component of how we construct meaning, in regards to both ourselves, our fellow human beings and the world. Thus, history shapes existential, ideological, moral and pedagogical aspects of our lives. If we want to argue or establish something about ourselves or our societies, we often use history to do so (cf. Karlsson 2014). Following this line of argumentation, we can say that there is a kind of inherent tension in history: It is something which we both use to make sense of things and which we, more or less, may come to take for granted (or even should take for granted). Yet it is also something that is constructed, provisional, contingent and, thus, dynamic. A challenge for any history teacher is to try to relate to this tension whenever he or she teaches history. Furthermore, history teachers are also individuals with personal experiences, interests and beliefs that affect how they view themselves, their fellow beings, the world and, therefore, history. From a perspective on pedagogical approaches to history, then, it becomes a matter of whether these approaches engage with this tension, or if they are particularly orientated towards representing and reproducing specific historical narratives. There is a strong consensus in history education research that pedagogical approaches ignoring the constructed nature of history are problematic, since they may foster a limited understanding of history and result in chauvinism and intolerance. The proposed solution is to teach history as critical inquiry and to foster historiographical insights, instead of merely presenting a particular historical narrative (Foster and Padgett 1999; Lévesque 2008; Seixas 2000; Wineburg 2001). Through a rational, autonomous stance towards the subject of history, a position commonly referred to as historical thinking, pupils (and others) will be able to approach historical narratives and history carefully and will not be swayed 
by the normative pull of history. I argue, however, that this is a formidable challenge due to the role history plays in our commonsense assumptions about ourselves and the world. Additionally, the education students receive in the subject is always a cultural and ideological enterprise; the subject matter which we apply our historical thinking to therefore goes beyond matters of critical inquiry (Thorp 2017). Even historians are affected by the cultural contexts in which they live and work.

I argue that an important means of acknowledging and involving this tension in our study of history and our pedagogical methods of teaching the same subject is to focus on matters pertaining to historicity and historical consciousness, i.e. an awareness of how all historical narratives and all our encounters with these narratives exist in time. This means that everything historical is contingent on historical factors and is thus open for reinterpretation. Historical consciousness should here be understood as the ever-present awareness that all human beings and all forms of social integration they have created exist in time, i.e. they are subject to historicity. Historical consciousness is manifested in human representations and conceptions, and results in an understanding or appreciation of how contextual contingency is inherent in these representations and conceptions, thus safeguarding common human rationality (Jeismann 1979). In this sense historical consciousness should be regarded as a kind of epistemic stance towards history that enables the individual to appreciate how history is reconstructed but at the same time omnipresent in all our encounters and uses of it. Approaching historical consciousness like this puts focus on the inherent tension in history outlined above: history is there for us to critically scrutinise and construct, but it is also the fabric of the historical meaning we make. This means that the critical gaze should not only be turned outwards towards historical accounts that we encounter, but also inwards towards our own meaning making and conceptions of history (Parkes 2011).

In order to empirically analyse how we epistemologically approach history and historical narratives, I devised a model of narratological uses of history in order to exemplify and categorise how we make use of history from the perspective of historical consciousness. Borrowing from and modifying Jörn Rüsen's typology of historical narratives (2012), I formu- 
lated three cognitively and narratologically different ways of using history: (i) A traditional narratological use of history presents history as static and acontextual, (ii) A critical narratological use of history attempts to destabilise other historical narratives or presents alternative historical narratives; and (iii) A genetic narratological use of history portrays history as dynamic, contingent and characterised by continuity and change (Thorp 2017, 132).

If we understand historical consciousness as an awareness of historicity, we can claim that historical consciousness should be understood as an epistemic approach towards history. If we are aware that history is a result of interpretation and reconstruction that historians (and others) make, we have a different kind of understanding of history than if we did not possess such an awareness. These different kinds of understanding of history correspond to the narratological uses of history above. A traditional use of history disregards how history is always the result of interpretation and reconstruction and instead presents history in a factual way; it purports that when we study history we can understand what really happened. A critical use of history uses history in a way that straddles the distance between the traditional and the genetic uses of history, since history is perceived as something that is contingent on perspective and interpretation, although there remain correct ways of understanding history. This can either result in a kind of relativistic stance towards history (meaning that all historical accounts are equally true or false) or in an understanding that claims that some historical accounts are 'true' and others are not (in the traditional sense of the term). A genetic use of history instead focuses on how all historical accounts and all approaches to history are characterised by interpretation, perspective and meaning making and is inevitably contingent on these factors. Here we can see a close theoretical connection to historical consciousness, as an awareness of historicity.

If we relate this framework to the study at hand, it becomes important to look not only at the content covered in class and the framing of that content, but also at the presentation of the content. Do the teachers engage with the entanglements of the Cold War, or do they present the pupils with a traditional narrative of how the events unfolded? It becomes 
more relevant to analyse the tasks and assignments the students are presented with: do they invite discussions of the complexity of the historical event at hand and the multitude of possible relationships to it, or are the pedagogical approaches used aimed at inculcating students with a particular historical account of the Cold War which they then unconsciously internalise?

In my initial analysis of the material, I analysed the teaching methods and materials the teachers employed when introducing the Cold War. I further analysed what pedagogic approach each teacher used in their respective classroom. For instance: Was the lesson focused on pupil activity or was it more of a session to orient the pupils? The next step in the analysis was to look at the content covered in these opening lessons. Who were the most prominent figures, what was the Cold War about? What aspects of the Cold War were highlighted and how was this content framed? The final stage of the analysis was directed at analysing how the teachers approached the lesson content from the perspective of engaging historical consciousness and narratological uses of history. This means that particular attention was paid to how the two teachers engaged with the entanglements and tensions of history and the teaching of history which were highlighted above.

\section{Results}

\section{Teaching strategies and educational media}

The two observed lessons show two distinctly different teaching strategies, but also some important similarities. The Swiss lesson could be characterized as pupil centered, although the teacher was in full control of the assignments and the content covered. The class began with the teacher showing the pupils the cartoon 'Tour du Monde: Tandem oder Einrad' by Jean Leffel, printed in the German textbook Menschen in Zeit und Raum 9 (2012, 113; see the introduction to this section). This cartoon depicts Harry S. Truman and Joseph Stalin riding bicycles. In the above 
picture we see them riding a tandem bicycle. Truman is in front and seems to be in charge of the direction they're going, with Stalin helping him. We could interpret this as relating to the relationship between the two during the Second World War and the fight against Hitler. The expressions on their faces are those of contention. The picture underneath shows Stalin and Truman riding unicycles in opposite directions. Their bodily poses and facial expressions are equally defiant. What I find particularly interesting with this cartoon is the historical message it seems to convey: Stalin and Truman (i.e. the USA and the USSR) both acted defiantly after the end of the Second World War, and thus both could be blamed for the escalation of the Cold War conflict. This is at odds with the typical Western view of the Cold War, which posits Stalin and the USSR as solely responsible for the Cold War (Holmén 2006; Ritzer 2012; Thorp 2015).

The pupils in the Swiss classroom were instructed to reflect on how the cartoon relates to a film about the American bombings of Hiroshima and Nagasaki and the extent of the destruction it caused. The teacher then returned to the cartoon and asked the pupils to discuss how they thought the cartoon related to the film they had just been shown. The most part of the lesson was devoted to this activity. While the pupils' answers drove the ensuing discussion in class and they were quite active, the teacher was still in control of the direction of the discussion, using various prompts and leading questions. The pupils were then asked to perform a role play activity, in which they read quotations by Harry S. Truman and Andrei Zhdanov, each arguing that the political orientations of their respective countries after the Second World War were the correct ones. The pupils were then asked to perform mock debates where they pretended to be either Truman or Zhdanov. At the end of the lesson the discussion in class was directed towards Germany and Japan and the culpability these nations should share for their actions during the Second World War. German nationalism, for instance, was problematized in relation to how the Germans celebrated the World Cup victory in football with flags. Pupils commented on how this outburst of national pride in particular made some Germans feel uneasy due to their past experiences with nationalism. Finally, the teacher 
directed the discussion towards the agenda the Allied forces decided on in relation to Germany.

The Swedish teacher used a different strategy. The lesson started with the teacher briefly, but still comprehensively, introducing the Cold War. The teacher's narrative was oriented towards giving the pupils an understanding of what the Cold War was and when it took place, and the narrative focussed on the conflicts of the Cold War; the teacher stressed that it was a war between the USA and the USSR fought by proxy. She also, when discussing Sweden's role during the Cold War, emphasised how Sweden was neutral in the conflict but that there was also a long tradition of conflict with Russia in Sweden, which prompted the Swedish government to orientate themselves towards the West and the USA. The next activity involved showing the pupils a French documentary film about the origins and escalation of the Cold War conflict. As an introduction to this activity the teacher introduced historiographical aspects, focussing on how history is always presented for a purpose and that it is contingent on this purpose. She then asked the pupils to reflect on whether the film might present a Western or Eastern perspective on the conflict, given that it is of French origin. The pupils replied that the film would probably be told from a Western perspective.

In brief, the film's narrative of the conflict focussed on the USA and USSR as two countries with similar pasts that cooperated during the war against Germany, but then came to oppose each other. In my view, the reason for the conflict between the USA and USSR is related to Stalin's breach of the Yalta conference agreement and the imposition of communist dictatorships in the countries that were occupied by the Red Army. These actions then made the USA realise that there was a communist threat and that they had to act upon this threat. This is what could be called the traditional Cold War narrative (Lundestad 2004). Throughout the showing of the film the teacher commented on what she perceived to be key aspects of the film's narrative. The teacher then ended the lesson by summing up and stressing the key features of the lesson: (i) the Cold War is a period that has shaped our present society, (ii) it was a troublesome period and (iii) Sweden was frightened of the USSR and chose to orient itself towards the West. 


\section{Historical content}

The Swiss lesson centred around two aspects of the Cold War period, i.e. the origins of the conflict and the reverberations of the Second World War on Germany and Japan. Regarding the origins of the conflict, the Swiss teacher placed great emphasis on explaining the conflict as a power struggle between the USA and the USSR and tried to ascribe agency to both actors. The cartoon used in the beginning of the lesson illustrated this well: in it, both Truman and Stalin are both unwilling to cooperate and thus both responsible for the escalation of the conflict. Furthermore, Truman and the USA are depicted as in charge of the course of events before the end of the Second World War and might in this sense be regarded as having the upper hand in the relationship between the two. This impression was further accentuated by the film portraying the American atomic bombings in Hiroshima and Nagasaki the teacher chose to show her pupils, and the assignment she gave them to relate the cartoon to the film's content. The aim here seemed to be to show that the USA and their military capacities did pose a threat towards Joseph Stalin and the USSR. This conclusion was further strengthened by the discussion between the teacher and the pupils that followed after the film.

To begin with, the teacher asks her pupils ' $\mathrm{OK}$, right then, this film, what it showed, does that connect at all with the cartoon? And if so, how?' A pupil replies after some reflection:

Yes, it is easy to explain, first they worked together. And then [...] Hiroshima happened. And then they [the USA and the USSR] split up and that made the world split up, actually.

In this interpretation, that went unchallenged by the teacher, you could argue that the USA caused the conflict through its atomic bombings in Japan. The teacher then instructed her pupils to look at the top picture of the cartoon (showing Truman and Stalin riding a tandem bicycle) and asked them 'Who's got the better seat on the tandem?' A pupil then replied, 'Yes, it's Stalin. Because he actually has to do, you know, less work. I mean, he had to do less pedalling, but he couldn't decide [where to go]'. The teacher is not entirely content with this interpretation and 
replies: 'Quite. But on the other hand, you already mentioned, the one in front can steer', suggesting that Truman had the better seat, after all.

Focus then shifted towards the bottom picture of the cartoon (showing Stalin and Truman riding unicycles in opposite directions). The teacher asked the students 'Are the proportions right in the bottom [picture], the two unicycles? Would they be right at that [particular] time [in history]?' The teacher here wanted her pupils to reflect upon whether the USA and the USSR entered the conflict on equal terms, as is suggested by the picture. Two pupils replied that they thought the proportions were right due to the spread of communism in the world after the Second World War. The teacher then replied:

Yes, that's right. From the point of view of population numbers, it's a good idea. Which aspect of [the relationship between the USA and the USSR] is not featured here? What else should there be here, again relating to the USA? Perhaps, [...] they've got the upper hand? For what reason, at this particular moment in time? (Swiss teacher)

To which a pupil replied, 'Because they're the only country in the world that had the atom bomb'. This reply seemed to satisfy the teacher as she replied: 'Yes, precisely. OK, then, I think you have interpreted this cartoon here well'. The teacher here seemed to be intent on stressing the role of the USA in the conflict, even though her pupils seem more inclined towards thinking that Stalin and the USSR did indeed pose a threat and had the upper hand in the conflict. The teacher then asked the pupils to rank the USA's world standing after the Second World War, and a pupil replied that they were number one both economically and militarily. The teacher confirmed this and then asked the pupil to explain why the USA should be ranked as number one militarily; the pupil then replied that it was because of the atom bomb.

When asked how they might rank the USSR, a male pupil replied that 'America's scared of this communism thing. And the Soviet Union is making propaganda against capitalism [...]'. He further added that that USSR was also gaining land, which he connected to the fall of the Iron Curtain and the division of Europe into East and West. To this the teacher replied: 'Exactly. Let's look at the war now. Perhaps you remember the US entering the war or, put a better way, the Soviet Union was attacked and 
the consequence was huge losses, millions of victims', again stressing the inferiority of the USSR compared to the USA. A pupil then replied that the USSR should be ranked in second place. The teacher then went on the sum up the discussion:

They [the USSR], I mean, they're winners too, aren't they. [...] It became clear that communism is an alternative to this liberal democracy. Clear as day, that's the alternative. And why shouldn't communism be the best model? With communism you can win wars. So here: communism as an alternative form of society. (Swiss teacher)

Here, the teacher reiterated what, it could be argued, is a part of her own agenda with the assignment: In 1945 the USA was by all means the world leader and was in possession of the atom bomb. The USSR had suffered great losses in the war and was therefore inferior to the USA. Furthermore, by winning the war against Germany, the USSR had also shown that communism was a legitimate alternative to the liberal capitalist democracy.

The next activity was a role play activity in which pupils were given quotations by Truman and Zhdanov and were asked to perform a mock debate where they should argue that their country's trajectory after the Second World War was a legitimate one. According to the pupils, Truman's main argument was that the USA is there to protect 'free people, $[\ldots]$ people should choose for themselves'. Zhdanov's argument was interpreted by a pupil as a kind of 'conspiracy theory',

I mean [they actually said that] America just because of their economic interests took part in the war and that [it] has imperialistic features, [...] and that the communist and democratic countries, to which [the USSR] count themselves, are fighting against this [imperialist] injustice. (Male Swiss pupil).

Here the pupil distanced himself from Zhdanov's interpretation of why the USA entered the Second World War. He then continued:

I have the feeling that both major powers want to put themselves, I mean, in a good light and [...] have a sort of trailblazing role. I mean for instance when America says: "Yes, we want to respect everyone, we want everyone to decide things for themselves". And Russia's doing exactly the same, but 
history shows us something else. That afterwards they actually didn't independently or selflessly support other countries, if we look at, for example, the war in Afghanistan.

To which the teacher replied: 'So both [have] the same role, probably using the same means. We'll see this later on'. The teacher then shifted attention from the USA and the USSR towards Germany and Japan at the end of the Second World War. She asked her pupils 'Now at the end of the war [...] what image [...] does humanity have of these two states [Germany and Japan]'. A pupil replied that people thought that Germany and Japan had to suffer the consequences of being 'megalomaniac', suggesting that their fault lay in being too hungry for power and world domination. The teacher, however, seemed to have something else in mind as well. She asked:

And on top of that? I mean, [what about] what happened in Germany with the racial ideology that was put into practice? And Japan also committed unbelievable atrocities [during] the war. How is that received, how do people approach the Japanese and the Germans [...] after everything that people realized was happening there? (Swiss teacher)

A pupil here replied that people became aware that 'people were capable of a lot [more] than we used to think'. Another pupil then went on: '[...] People had suddenly found the scapegoat for everything'. The Germans and Japanese 'had to pay' for the war. The teacher then stressed another aspect of this and asked her pupils to reflect upon how people still regard Germany and Japan morally, 'to this day'. One female pupil replied that:

Yes, it's the same to this day. But for them personally as well. [...] I was at a camp there were three Germans there and we were talking about it and they said it was so extreme that the first time they could hang German flags again was four years ago when the World Cup [in football] was on. (Swiss female pupil B)

The pupil here suggested that this sentiment still affects Germany and Germans today. The remainder of the lesson was devoted to outlining 
the denazification process in Germany after the war and how Nazis managed to escape justice because of a lax effort on the part of the Allied forces and the USA in Western Europe and the active support of the Vatican.

The Swedish lesson was introduced comprehensively by the teacher, as she outlined what the Cold War was about and then tried to relate it to the Swedish national context. When discussing the definition of the Cold War, she warned her pupils not to think of the Cold War as related to winter but instead asks her pupils to imagine a metaphor:

Imagine that you just entered a room where your mother and father just had a row, or two of your friends had a row, or something similar. You enter the room and feel [...] in the atmosphere that something has happened, or that there is a risk that something will happen. You maybe have been in a fight with someone and argued and you have been very close to losing control, and that is a symbol of what the Cold War is. (Swedish teacher)

She then went on the explain that the Cold War was a war fought by proxy between the USSR and the USA, with Sweden being neutral but caught in between the two powers. Concerning Sweden's stance towards the USA and the USSR, the teacher stressed that:

We are neutral, and that means that Sweden during this period in history and still today lie in-between [the USA] and [the USSR]. But then we also have a tradition. If you ask grown-ups at home, they will tell you that they are a little bit more scared of [the USSR]. And historically we can explain this by Sweden more often [...] having fought [the USSR] than [the USA]. (Swedish teacher)

The teacher then asked her pupils to reflect on what the Cold War can be if it is not a traditional war fought between two belligerents. The pupils replied that it was a war about politics, technology and Germany, to which the teacher repeated that this was a war fought by proxy and asked her pupils to imagine a situation where they are unfriendly with someone and asks their friends to attack this person. The teacher then went on to introduce a film about the emergence of the Cold War conflict, but before 
she shows the pupils the film she asks them to reflect on historiographical aspects of history:

When you study history it's extremely important that you always think, and this is not only in relation to the Cold War, but also when we write history today, when your grandchildren will read the history books they will assess "Who wrote this?" and "Did this really happen?" [...]. It's really important when you study history, when something has been passed on [or told by someone else], [to reflect] on whether it's true or false and if it has been written for a specific purpose. (Swedish teacher)

She then told her pupils that the film they are about to watch is French and whether France was on the American or Soviet side of the conflict. A pupil replied that they were on the side of the USA. This was confirmed by the teacher, who adds 'and then maybe they regard the conflict in a certain way'. She then left the historiographical aspect to one side and played the film to the class.

In the film a voice over narrates a history of the emergence on the conflict centered on how US and British troops advanced into Germany from the west and Soviet troops advanced from the east. It is then explained that the USSR was a 'dictatorship of the proletariat' and that Soviet economy and political activity was state controlled. The USA is described as a country where the government's power is regulated and where private ownership and free competition is regarded as a guarantee for the well being of its citizens. Regarding the escalation of the conflict between the USA and the USSR, Stalin's breach of the Yalta conference agreement and imposition of communism in the countries occupied by the Soviet troops is presented as a key event, which made the USA realise that the USSR posed a threat to world peace and security, prompting Truman to issue his declaration. Here, the Swedish teacher interjected with: 'In Sweden you said: "The Russian is coming, the Russian is coming, be wary of the Russian [...]'. The lesson was then ended by the teacher summing up the content of the day's lesson:

What we have started with today and will study in the coming two weeks is a period that has meant a lot to me because I have lived during this 
period. It has also meant a lot to your parents and grandparents because there was a situation in the world [...] where [the USSR] and [the USA] distrusted each other, they were very afraid of each other and sometimes during this period, starting 1945, things got heated [and war was very close]. So, it's a troublesome time and Sweden tries to be neutral but from tradition we have been more afraid of [the USSR], and therefore we approached [the USA]. (Swedish teacher)

\section{Narratological uses of history}

As has been shown above, these two lessons provide us with two rather different approaches to introducing the Cold War, but there are also similarities between the two pedagogical approaches in regards to how history is used narratologically. In the Swiss lesson, the teacher seemed to have a personal agenda with an introduction that was oriented towards destabilising the traditional grand narrative of the Cold War as a result of Soviet aggression. The teaching material used, i.e. the cartoon, the film segment and the quotations from Truman and Zhdanov, all seem to support this conclusion. The cartoon shows us how Truman and the USA were in charge of matters and how Stalin and Truman defiantly headed in different directions at the end of Second World War. The film segment highlights how US bombings in Japan wreaked havoc and that the USA had a terrible weapon of mass destruction that they were willing to deploy. Furthermore, the quotations from Zhdanov and Truman ascribe agency to both actors and gives voice to the Soviet interpretation of what was happening in Europe and across the world, i.e. that the USA was an imperialist force intent on imposing their model of society on the world. Throughout the lesson the pupils did, however, give voice to what may be the implicit commonsense assumptions concerning the conflict in Swiss historical culture. This was evidenced, for example, when a pupil interpreted Zhdanov's view of the world as a conspiracy theory and an example of hypocrisy. The teacher engaged with these views throughout and attempted to direct the discussion towards an understanding of how the USA was also an aggressive force, one which had the upper hand in relation to the USSR in 1945 . Perhaps the teacher was trying here to 
show an alternative way of interpreting events after 1945, to challenge commonsense assumptions about the Cold War. This could be a risky enterprise since the teacher could come across as politically and ideologically motivated (and therefore less credible) in trying to put forward an alternative view of the Cold War, but there are no indications that the pupils perceived her this way.

From a pedagogical perspective on history, it could be argued that the repeated clashes between the teacher's agenda and the pupils' insistence on a traditional rendering of the Cold War provided many opportunities for a discussion about the role perspective plays in how we understand history, highlighting how history both underlies our understanding of the world, but also remains contingent on how we approach it. This opportunity was, however, not explicitly grasped by the teacher who instead repeatedly challenged her pupils' interpretations and directed them towards accepting her own interpretations of both the media used in the class and the reasons behind the Cold War. In this sense, you could say that the Swiss teacher chose to use history critically, seeking to destabilise one way of understanding the origins of the Cold War by proposing another approach to the topic.

The Swedish lesson differed in that the Cold War was addressed by the class as a whole. The teacher (and then a film) narrated a version of the Cold War. Here we might argue that the pedagogical approach taken facilitated an understanding of the conflict and history as something fixed and stable, the teacher spelling out the origins of the Cold War. The teacher repeatedly reached out to her pupils during her presentation and tried to engage them in the subject with personal and private analogies, i.e. the Cold War as a family row, the war by proxy as attacking someone through your friends. These analogies were, however, directed towards facilitating an understanding of the Cold War. In this sense history is presented transparently: no specific perspective or construction is discernable (cf. Ankersmit 2013).

One interesting facet to this lesson was that the teacher introduced historiographical aspects before the showing of the film. She urged her pupils to think about how history can be constructed for particular purposes by different groups of people, both in the class and in the future. She further remarked on how narratives can become distorted when they 
are retold or passed on by people. The Swedish teacher here addressed two aspects of history and historical truth: the idea that history is always contingent on perspective (and therefore suspicious), and the difficulty of knowing what is 'true' in history. It could therefore be argued that the Swedish teacher pushed toward her pupils a kind of relativistic notion of history (it is only a matter of perspective) and the idea that historical truth concerns primarily whether the narrative at hand corresponds with or does not correspond with original events. These two views on historical truth might be understood as conflicting, since one is relativistic in relation to truth, and the other is what could be called a classical positivist notion of truth and history. This makes it difficult to understand what message the Swedish teacher intended to convey to her pupils. Here the teacher had what could have been an excellent opportunity to discuss the historiographical aspects of the narrative presented by both herself and the film and to engage with the Western historical cultural context of these interpretations of the Cold War, but instead the teacher chose to resume the lesson with the narrative at hand. Thus, you could argue that the Swedish teacher used history traditionally in the observed lesson, since the pupils were presented with one narrative and one perspective on events after 1945 .

\section{Discussion: cultural entanglements and historicity}

The results above reveal that the perception of the Cold War as a conflict between the USA and the USSR is a commonly held assumption when it comes to defining the Cold War, regardless of who might be at fault for causing it. Both lessons centred around this frame when addressing the period after 1945 and no teacher mentioned, for instance, that the period after 1945 was also one of unprecedented improvement in living standards for people in Switzerland and Sweden. The period furthermore saw the introduction of the welfare state in these countries and in most cases further democratisation, historical examples which can be used to problematise the commonsense understanding of the Cold War. 
The Swiss lesson was characterised by the teacher's method of engagement with the past and her encouragement to her pupils to do the same: the definition of the Cold War is not something that is once and for all settled but it is still contingent on whose version we are getting. In this way the Cold War is a topic used to provoke not only ideological but also moral discussions, as in the example of how the world viewed Germany and Japan after the Second World War. In this sense, the teacher showed that the Cold War is an event that still affects us and shapes how we view the world. There was, however, a kind of distancing in the Swiss lesson that was brought about by the focus on international affairs and international politics. Switzerland and its role in the world after 1945 was not mentioned at all in the observed lesson.

The Swedish lesson was also characterised by engagement, but in contrast to the Swiss lesson, this engagement did not concern how we might understand the Cold War. Instead, the engagement in this lesson was related to how the teacher perpetually related the events after 1945 to national and personal perspectives, portraying Sweden as caught inbetween the USA and the USSR, perhaps even helpless. This was accentuated by the teacher's repeated gesturing to a long Swedish tradition of war with Russia, which pushed Sweden towards the USA and the West. Concerning such engagement, we might note how the teacher related the Cold War to her own upbringing and her pupils' parents and grandparents, emphasising that it was an event that affected these groups a lot and, furthermore, how the pupils' older relatives might also vouch for Russia and the USSR traditionally having posed a threat to Sweden. Significant too, in the Swedish lesson, was the stress the teacher put upon the atmosphere of the Cold War period as one which was fearful and troubled. Sweden was afraid of the USSR, and the USA and the USSR were also afraid of each other. Thus, the Swedish lesson reproduced cultural aspects of fear and distrust towards the USSR and Russia and, in a sense, might have even contributed to the reproduction of Russia as Sweden's eternal enemy. This is a trend that is strong in the Swedish historical culture of the Cold War (cf. Holmén 2006; Thorp 2015, 2017; Persson in this volume). Therefore, the Swedish teacher in this lesson presented the Cold War from a national and personal perspective: the conflict, either viewed from a national perspective or as part of wider international politics, she 
emphasised, is related to personal experiences (i.e. family relations or relations to friends) or personal feelings (e.g. the fear of the USSR and Russia).

Concerning how the observed lessons relate to the aspects of historicity and the ensuing inherent tension within the subject of history, we can say that even though the two teachers in our case studies manifested a variety of pedagogic strategies and approaches to the Cold War, none of these seemed directed towards raising questions regarding how our own positions might affect how we render history and make sense of the past. Instead, we observed that both teachers chose to approach history as a knowable past impervious to perspective and interpretation. While the Swiss teacher seemingly aimed to destabilise one particular perspective on the Cold War, she nevertheless constructed an alternative understanding that is posited as more legitimate. The Swedish teacher presented one narrative of the Cold War in a personal and affectionate manner, seeking to engage her pupils on a personal level, but this narrative did not invite her pupils to relate to either the Soviet or Eastern perspective in a personal sense, even though this would also have been possible. Consequently, both lessons reproduced perspectives of history which disregard how history is always, and must be, contingent on both how and why different parties choose to approach it.

\section{Concluding remarks}

As I pointed out in the introduction to this article, the teaching of history is a complex enterprise that poses challenges to history teachers for a variety of reasons. The lessons described here provide good examples of how a historical topic might be approached in the course of teaching history. Lessons in which pupils are active and contribute to shaping the historical topic presented provide rewarding ways of prompting pupils to engage with and relate to the historical topic at hand. When pupils are presented with narratives which invite them to reflect on the historical topic on a personal level, in order to make sense of what is portrayed, we witness another potentially effective method of bringing history to life for 
these students and showing them how it has personal relevance for all learners.

Still, the examples presented here also stress the challenges of teaching history, which inevitably crop up due to the subject matter, and reveal the importance of historical self-awareness and historical consciousness. Such recognition is important in order to enable us to engage with the provisional, contingent and dynamic character of history at the same time as we reconstruct and make sense of it. This may be an easy task to describe in theory, but it is a lot harder to do in practice. It is my wish that this chapter may be used to inspire new perspectives on how we may approach the teaching of history, both to highlight the pedagogical challenges and complexities of the subject and to emphasise the importance of history as a subject in schools and elsewhere.

\section{Bibliography}

\section{Textbook Cited}

Menschen in Zeit und Raum 9. Edition for Lower Saxony. Zürich: Schulbuch Verlag plus AG, 2012.

\section{Bibliography}

Ankersmit, Frank. 2013. 'Representation as a Cognitive Instrument'. History \& Theory 52, no. 2:171-93.

Duraisingh, Elizabeth Dawes. 2017. 'Making Narrative Connections? Exploring How Late Teens Relate their Own Lives to the Historically Significant Past'. London Review of Education 15, no. 2: 174-93.

Foster, Stuart J. and Charles S. Padgett. 1999. 'Authentic Historical Inquiry in the Social Studies Classroom'. The Clearing House: A Journal of Educational Strategies, Issues and Ideas 72, no. 6: 357-63.

Furrer, Markus. 2017. 'A View of the Cold War in the Swiss Historical Narrative'. In Remembering and Recounting the Cold War: Commonly Shared History?, ed. by Markus Furrer and Peter Gautschi. 111-28. Schwalbach: Wochenschau Verlag. 
Furrer, Markus and Peter Gautschi. 2017. 'Memory Cultures and History Education. Introduction'. In Remembering and Recounting the Cold War: Commonly Shared History?, ed. by Markus Furrer and Peter Gautschi. 11-26. Schwalbach: Wochenschau Verlag.

Gadamer, Hans-Georg. 1975. 'The Problem of Historical Consciousness', ed. by Erick Raphael Jimenez, Matthew Lampert, Christopher Roberts, and and Rocío Zambrana. Graduate Faculty Philosophy Journal 5, no. 1: 8-52.

Holmén, Janne. 2006. 'Den politiska läroboken: Bilden av USA och Sovjetunionen i norska, svenska och finländska läroböcker under kalla kriget'. Studia Historica Upsaliensia 0081-6531; 221. Uppsala: Acta Universitatis Upsaliensis.

Jeismann, Karl-Ernst. 1979. 'Geschichtsbewußtsein'. In Handbuch der Geschichtsdidaktik, ed. by Klaus Bergmann, Annette Kuhn, Jörn Rüsen, and Gerhard Schneider, 1st ed. 42-45. Düsseldorf: Pädagogischer Verlag Schwann.

Karlsson, Klas-Göran. 2014. 'Historia, historiedidaktik och historiekultur teori och perspektiv'. In Historien är närvarande: Historiedidaktik som teori och tillämpning, ed. by Klas-Göran Karlsson and Ulf Zander. 13-89. Lund: Studentlitteratur.

Lévesque, Stéphane. 2008. Thinking Historically: Educating Students for the Twenty-First Century. Toronto: Buffalo.

Lundestad, Geir. 2004. Öst, väst, nord, syd: Huvuddrag i internationell politik efter 1945 Lund: Studentlitteratur.

Parkes, Robert J. 2011. 'Interrupting History: Rethinking History Curriculum after "The End of History". In Counterpoints: Studies in the Postmodern Theory of Education, 404. New York: Peter Lang Publishing.

Parkes, Robert J. 2013. 'Postmodernism, Historical Denial, and History Education: What Frank Ankersmit Can Offer to History Didactics'. Nordidactica: Journal of Humanities and Social Science Education 2 (2013): 20-37.

Persson, Anders. 2017. 'Lärartillvaro och historieundervisning: innebörder av ett nytt uppdrag i de mätbara resultatens tid'. Umeå studies in history and education 18. Umeå: Umeå universitet.

Persson, Anders and Robert Thorp, 2017. 'Historieundervisningens existentialiserande potential'. Nordidactica: Journal of Humanities and Social Science Education 2 (2017): 59-74.

Ritzer, Nadine. 2012. 'The Cold War in Swiss Classrooms: History Education as a "Powerful Weapon against Communism"?' Journal of Educational Media, Memory, and Society 4, no. 1: 78-94. 
Roth, Paul A. 2012. 'The Pasts'. History \& Theory 51 (October): 313-39. Rüsen, Jörn. 2012. 'Tradition: A Principle of Historical Sense-Generation and Its Logic and Effect in Historical Culture'. History and Theory 51, no. 4: 45-59.

Seixas, P. 2000. 'Schweigen! Die Kinder! or, Does Postmodern History Have a Place in the Schools?' In Knowing, Teaching, and Learning History: National and International Perspectives, edited by P.N. Stearns, P. Seixas and S. Wineburg, 19-37. New York: New York University Press.

Stymne, Anna-Karin. 2017. Hur begriplig är historien? Elevers möjligheter och svårigheter i historieundervisningen i skolan. Stockholm: Stockholm University Press.

Thorp, Robert. 2015. 'Representation and Interpretation: Textbooks, Teachers, and Historical Culture'. IARTEM E-Journal 7, no. 2: 73-99.

Thorp, Robert. 2016. 'Uses of History in History Education'. Umeå Studies in History and Education 13. Umeå: Umeå universitet.

Thorp, Robert. 2017. 'Experiencing, Using, and Teaching History: Aspects of Two History Teachers' Relations to History and Educational Media'. Journal of Educational Media, Memory, and Society 9, no. 2: 129-46.

Wilschut, Arie. 2012. Images of Time: The Role of an Historical Consciousness of Time in Learning History. Charlotte, NC: Information Age Publishing.

Wineburg, Sam. 2001. Historical Thinking and Other Unnatural Acts: Charting the Future of Teaching the Past. Philadelphia: Temple University Press.

Zanazanian, Paul. 2009. Historical Consciousness and the Construction of InterGroup Relations: The Case of Francophone and Anglophone History School Teachers in Quebec. Montréal: Université de Montréal. 
Open Access This chapter is licensed under the terms of the Creative Commons Attribution 4.0 International License (http://creativecommons.org/licenses/ by/4.0/), which permits use, sharing, adaptation, distribution and reproduction in any medium or format, as long as you give appropriate credit to the original author(s) and the source, provide a link to the Creative Commons licence and indicate if changes were made.

The images or other third party material in this chapter are included in the chapter's Creative Commons licence, unless indicated otherwise in a credit line to the material. If material is not included in the chapter's Creative Commons licence and your intended use is not permitted by statutory regulation or exceeds the permitted use, you will need to obtain permission directly from the copyright holder.

(c) (1) 